\title{
PENGARUH STRUKTUR KEPEMILIKAN DAN UKURAN PERUSAHAAN TERHADAP PENGUNGKAPAN MANAJEMEN RISIKO
}

\author{
Edo Bangkit Prayoga \\ Luciana Spica Almilia \\ STIE Perbanas Surabaya \\ Email: lucy@perbanas.ac.id
}

\begin{abstract}
Every company inevitably face risk in terms of financial risk or operational risk. In an uncertain economic situation, risk management is one way to reduce and deal with any risk that the company may face. This study aimed to analyze the effect of managerial ownership, domestic institutional ownership, foreign institutional ownership, public ownership and firm size on the risk management disclosure. The population used here was secondary data from the Indonesia Stock Exchange (BEI), i.e. the annual reports of listed manufacturing companies in periods of the year 2007-2011. The sample study using purposive sampling and final data consisted of 189 companies. The statistical method used is multiple regression analysis, hipotesis test by $t$ test and $F$ test. the results of this study indicate that (1) managerial ownership has no effect on risk management disclosure (2) domestic institutional ownership affects the disclosure of risk management (3) foreign institutional ownership affects the risk management disclosure (4) public ownership affect the disclosure of risk management (5) does not affect the size of the company's risk management disclosures.
\end{abstract}

Keywords: Risk Management Disclosure, Ownership Structure, Firm Size

\section{PENDAHULUAN}

Semakin ketatnya persaingan bisnis, mendorong setiap perusahaan untuk lebih transparan dalam mengungkapkan informasinya. Lebih banyak pihak yang memiliki kepentingan terhadap perusahaan menyebabkan semakin banyak pula informasi yang perlu diungkapkan.

Informasi yang diungkapkan harus dapat dipahami, dipercaya, relevan, dan transparan, karena informasi tersebut menjadi dasar pengambilan keputusan bagi pengguna informasi tersebut khususnya pihak investor. Hal tersebut disebabkan kegiatan investasi merupakan suatu kegiatan yang mengandung risiko dan ketidakpastian. Karena risiko yang melekat ini, maka informasi yang disajikan oleh perusahaan diharapkan dapat mengurangi tingkat risiko dan ketidakpastian yang dihadapi oleh investor. Dengan demikian, maka diperlukan pengungkapan (disclosure) yang memadai (Sudamarji, 2007 dalam Fathimiyah dkk, 2011).

Pengungkapan (disclosure) memberikan implikasi bahwa keterbukaan merupakan basis kepercayaan publik terhadap manajemen di dalam sistem korporasi. Dengan kata lain, 
kualitas mekanisme corporate governance seharusnya dapat dilihat dari tingkat keterbukaan atau transparansi (Fathimiyah dkk, 2011). Banyak peneliti yang mengungkapkan bahwa salah satu faktor yang memperburuk kondisi Indonesia pada saat krisis tahun 1997 adalah lemahnya corporate governance. Hal ini ditandai dengan kurang transparannya pengelolaan perusahaan.

Manajemen risiko dimulai dari adanya kesadaran manajemen menyadari bahwa risiko itu pasti ada di dalam suatu perusahaan. Penerapan manajemen risiko yang baik harus memastikan bahwa organisasi tersebut mampu memberikan perlakuan yang tepat terhadap risiko yang akan mempengaruhinya (Susilo dan Kaho, 2010). Informasi mengenai manajemen risiko sangat berguna bagi para pemangku kepentingan, khususnya bagi para investor. Informasi ini berguna bagi investor untuk melakukan analisis risiko agar pengembalian yang diharapkan dapat terpenuhi. Manajemen risiko mempunyai peranan yang sangat penting dalam membentuk good corporate governance.

Mekanisme pengawasan dari corporate governance yang terdiri dari struktur kepemilikan yang meliputi kepemilikan manajemen, kepemilikan institusi domestik, kepemilikan institusi asing, kepemilikan publik (Hapsoro, 2007) dan ukuran perusahaan, dimana mekanisme ini dapat mengontrol perusahaan lebih optimal, sehingga dapat menurunkan konflik kepentingan (conflict of interest) yang disebabkan oleh masalah keagenan antara pemilik dan manajer. Kepemilikan manajemen adalah proporsi saham biasa yang dimiliki oleh para manajemen. Kedudukan manajer dengan pemegang saham dapat disejajarkan dengan meningkatkan kepemilikan saham oleh manajemen. Ririn (2011), mengungkapkan bahwa Kepemilikan institusi domestik merupakan kepemilikan saham perusahaan yang mayoritas dimiliki oleh institusi atau lembaga (perusahaan asuransi, bank, perusahaan investasi, asset management dan kepemilikan institusi lain). Kepemilikan asing adalah perseorangan warga negara asing, badan usaha asing, dan pemerintah asing yang melakukan penanaman modal di wilayah Republik Indonesia (Fathimiyah dkk, 2011). Kepemilikan publik adalah proporsi kepemilikan saham pada akhir tahun yang dimiliki oleh masyarakat umum (bukan institusi signifikan). Kepemilikan publik memiliki arti penting dalam memonitor manajemen serta mendorong peningkatan pengawasan yang lebih optimal dalam perusahaan. Ukuran perusahaan dapat diartikan besar kecilnya sumber daya yang dimiliki perusahaan tersebut, baik itu sumber daya modal ataupun sumber daya manusia yang dimilikinya. Besar (ukuran) perusahan dapat dinyatakan dalam total aktiva, penjualan, dan kapitalisasi pasar (Sudarmadji dan Sularto, 2007). Semakin besar ukuran perusahaan maka semakin banyak informasi yang akan diungkapkannya. Serta semakin detail pula hal-hal yang akan diungkapkan karena perusahaan besar dianggap mampu untuk menyediakan informasi tersebut.

Banyak penelitian terdahulu yang mengungkapakan struktur kepemilikan dan ukuran perusahaan memiliki pengaruh terhadap pengungkapan laporan keuangan perusahaan seperti Kumala Dewi (2009) yang menyatakan bahwa porsi saham publik berpengaruh positif terhadap luas pengungkapan laporan keuangan. Puspitasari, (2009) meneliti hubungan ukuran perusahaan dan porsi kepemilikan saham publik dengan tingkat pengungkapan laporan tahunan perusahaan. Serta Fathimiyah dkk, (2011) yang meneliti tentang pengaruh srtuktur kepemilikan terhadap risk management disclosure. Namun di Indonesia sendiri, penelitian tentang pengungkapan manajemen risiko masih sedikit.

Maka dari itu penelitian ini bertujuan untuk menetahui pengaruh dari ukuran perusahaan, kepemilikan manajemen, kepemilikan institusi domestik, kepemilikan institusi asing dan kepemilikan publik terhadap pengungkapan manajemen risiko.

Berdasarkan uraian di atas, struktur kepemilikan yang terdiri dari kepemilikan manajemen, institusi domestik, institusi asing, dan publik serta ukuran perusahaan yang 
mempengaruhi pengungkapan manajemen risiko masih menarik untuk diuji lebih lanjut, maka penelitian ini diberi judul "Pengaruh Struktur Kepemilikan dan Ukuran Perusahaan Terhadap Pengungkapan Manajemen Risiko".

\section{RERANGKA TEORITIS DAN HIPOTESIS}

\section{Teori agensi}

Perspektif hubungan keagenan merupakan dasar yang digunakan untuk memahami hubungan antara manajer dan pemegang saham. Jensen dan Meckling (1976) dalam Suranta (2003) menyatakan bahwa hubungan keagenan adalah sebuah kontrak dimana satu atau lebih (principal) menyewa orang lain (agen) untuk melakukan beberapa jasa untuk kepentingan mereka dengan mendelegasikan beberapa wewenang pembuatan keputusan kepada agen.

Pemegang saham menilai kinerja manajer berdasarkan kemampuannya dalam menghasilkan laba perusahaan. Sebaliknya, manajer berusaha memenuhi tuntutan pemegang saham untuk menghasilkan laba yang maksimal agar mendapatkan kompensasi atau insentif yang diinginkan.

Namun, manajer seringkali melakukan manipulasi saat melaporkan kondisi perusahaan kepada pemegang saham agar tujuannya mendapatkan kompensasi tercapai. Kondisi perusahaan yang dilaporkan oleh manajer tidak sesuai atau tidak mencerminkan keadaan perusahaan yang sesungguhnya. Hal ini disebabkan perbedaan informasi yang dimiliki antara manajer dengan pemegang saham. Sebagai pengelola, manajer lebih mengetahui keadaan yang ada dalam perusahaan dari pada pemegang saham. Keadaan tersebut dikenal sebagai asimetri informasi.

\section{Teori signal}

Menurut Wolk., et al. (2001) dalam Nuswandari (2009) teori signal menjelaskan alasan perusahaan menyajikan informasi untuk pasar modal. Teori signal menunjukkan adanya asimetri informasi antara manajemen perusahaan dan pihak-pihak yang berkepentingan dengan informasi tersebut. Teori signal mengemukakan tentang bagaimana seharusnya perusahaan memberikan sinyal-sinyal pada pengguna laporan keuangan.

Teori Signal menjelaskan mengapa perusahaan mempunyai dorongan untuk memberikan informasi laporan keuangan kepada pihak eksternal. Dorongan perusahaan untuk memberikan informasi karena terdapat asimetri informasi antara perusahaan dengan pihak eksternal. Perusahaan/manajer memiliki pengetahuan lebih banyak mengenai kondisi perusahaan dibandingkan pihak eksternal (Nuswandari,2009).

\section{Ukuran Perusahaan}

Besar (ukuran) perusahan dapat dinyatakan dalam total aktiva, penjualan, dan kapitalisasi pasar (Sudarmadji, 2007). Semakin besar perusahaan maka semakin banyak informasi yang akan diungkapkannya. Serta semakin detail pula hal-hal yang akan diungkapkan karena perusahaan besar dianggap mampu untuk menyediakan informasi tersebut.

\section{Kepemilikan Manajemen}

Kepemilikan manajemen adalah proporsi pemegang saham dari pihak manajemen yang secara aktif ikut dalam pengambilan keputusan perusahaan (Diyah dan Erman, 2009). 
Kedudukan manajer dengan pemegang saham dapat disejajarkan dengan meningkatkan kepemilikan saham oleh manajemen. Manajemen berperan penting dalam menjalankan perusahaan, karena manajemen tidak hanya mengelola perusahaan tetapi juga sebagai pemegang saham.

\section{Kepemilikan Institusi Domestik}

Kepemilikan institusi domestik merupakan kepemilikan saham perusahaan yang mayoritas dimiliki oleh institusi atau lembaga (perusahaan asuransi, bank, perusahaan investasi, asset management dan kepemilikan institusi lain) (Anggraini, 2011 dalam Fathimiyah dkk, 2011). Kepemilikan institusional merupakan pemegang saham terbesar sehingga merupakan sarana untuk memonitor manajemen (Djakman dan Machmud, 2008).

\section{Kepemilikan Institusi Asing}

Menurut Undang-undang No. 25 Tahun 2007 pada pasal 1 angka 6 kepemilikan asing adalah perseorangan warga negara asing, badan usaha asing, dan pemerintah asing yang melakukan penanaman modal di wilayah Republik Indonesia (Fathimiyah dkk, 2011).

\section{Kepemilikan Publik}

Kepemilikan saham publik adalah porsi saham beredar yang dimiliki masyarakat (Puspitasari,2009). Kepemilikan publik adalah kepemilikan masyarakat umum (bukan intitusi yang signifikan) terhadap saham perusahaan publik. Struktur kepemilikan perusahaan dapat disebut juga sebagai struktur kepemilikan saham, yaitu suau perbandingan antara saham yang dimiliki oleh pihak dalam atau manajemen ( insider ownership's) dengan jumlah saham yang dimiliki pihak luar (outsider ownership's) (Suharli dan Rachprilia, 2006 dalam Puspitasari, 2009).

\section{Pengaruh Ukuran Perusahaan terhadap Pengungkapan Manajemen Risiko}

Perusahaan yang besar dapat menyediakan laporan untuk keperluan internal, dimana informasi tersebut sekaligus sebagai bahan untuk keperluan informasi kepada pihak eksternal, sehingga tidak perlu mengeluarkan biaya tambahan. Semakin besar perusahaan maka semakin banyak informasi yang akan diungkapkannya. Semakin detail pula hal-hal yang akan diungkapkan seperti informasi tentang manajemen risiko perusahaan, karena perusahaan besar dianggap mampu untuk menyediakan informasi tersebut.

\section{Pengaruh Kepemilikan Manajemen terhadap Pengungkapan Manajemen Risiko}

Kepemilikan manajemen menunjukkan adanya peran ganda dari pihak manjemen, yaitu dewan direksi bertindak juga sebagai pemegang saham. Sebagai seorang yang mengelola perusahaan sekaligus pemegang saham tidak ingin perusahaan dalam keadaan kesulitan keuangan bahkan mengalami kebankrutan. Keadaan ini akan merugikan baik sebagai manajemen atau sebagai pemegang saham. Sebagai pihak manajemen akan kehilangan insentif dan sebagai pemegang saham akan kehilangan return ataupun dana yang diinvestasikannya (Diyah dan Erman, 2009).

Manajemen bertanggung jawab atas semua kegiatan usaha yang telah dilakukan dengan melakukan pengungkapan laporan tahunan. Semakin besar proporsi kepemilikan manajemen pada perusahaan, maka manajemen cenderung lebih giat untuk kepentingan pemegang saham dimana pemegang saham adalah dirinya sendiri yaitu dengan lebih detail dalam pengungkapan manajemen risiko. 
Pengaruh Kepemilikan Institusi domestik terhadap Pengungkapan Manajemen Risiko

Kepemilikan institusi domestik merupakan kepemilikan saham perusahaan yang mayoritas dimiliki oleh institusi atau lembaga (perusahaan asuransi, bank, perusahaan investasi, asset management dan kepemilikan institusi lain) (Ririn, 2011). Kepemilikan institusional merupakan pemegang saham terbesar sehingga merupakan sarana untuk memonitor manajemen (Djakman dan Machmud, 2008).

\section{Pengaruh Kepemilikan Institusi Asing terhadap Pengungkapan Manajemen Risiko}

Partisipasi asing pada perusahaan di Indonesia akibat globalisasi finansial dapat berupa meningkatnya kehadiran manajer-manajer asing. Meningkatnya permintaan dari konsumen asing yang membutuhkan pelayanan dari perusahaan domestik, atau meningkatnya utang-utang asing akibat aliran modal asing yang masuk (Sudarmono, 2011 dalam Fathimiyah dkk, 2011). Sehingga, jika semakin tinggi kepemilikan asing maka tingkat risikonya pun semakin besar. Maka pengungkapan tentang manajemen risiko dirasa semakin dibutuhkan.

\section{Pengaruh Kepemilikan Publik terhadap Pengungkapan Manajemen Risiko}

Kepemilikan perusahaan oleh pihak luar memiliki kekuatan yang besar dalam memengaruhi perusahaan melalui media massa berupa kritikan atau komentar yang semuanya dianggap sebagai suara masyarakat. Adanya konsentrasi kepemilikan publik menimbulkan pengaruh pihak luar sehingga mengubah pengelolaan perusahaan yang pada awalnya berjalan sesuai keinginan manajemen menjadi memiliki keterbatasan (Puspitasari,2009). Semakin besar porsi saham yang dimiliki publik, maka akan semakin besar tekanan yang diterima perusahaan untuk menyediakan informasi lebih banyak dalam laporan tahunannya yang di dalamnya terdapat pula pengungkapan tentang manajemen risiko.

\section{Gambar 1}

\section{Rerangka Pemikiran}

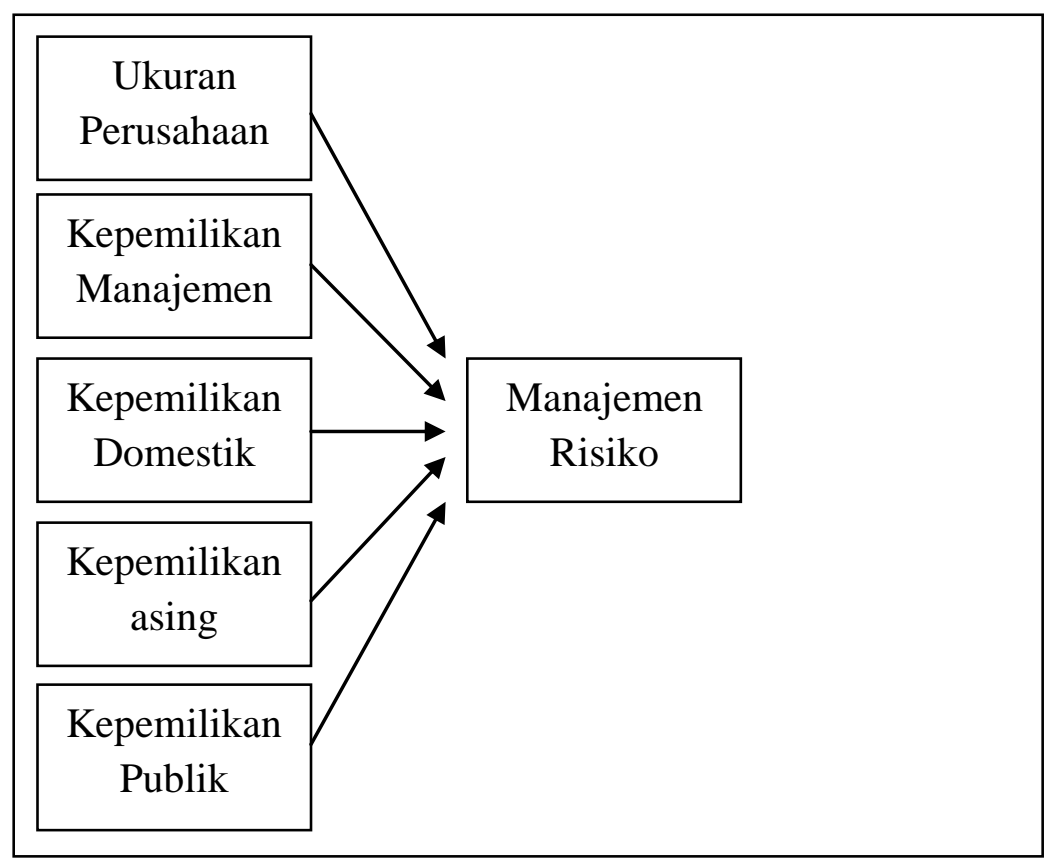


Berdasarkan hasil penelitian terdahulu serta pembahasan dan landasan teori yang ada, maka dalam penelitian ini dapat dibuat sebuah hipotesis sebagai berikut:

H1: Ukuran Perusahaan berpengaruh terhadap pengungkapan Manajemen Risiko

$\mathrm{H} 2$ : Kepemilikan manajemen berpengaruh terhadap pengungkapan manajemen risiko.

H3: Kepemilikan institusi domestik berpengaruh terhadap pengungkapan manajemen risiko.

H4: Kepemilikan institusi asing berpengaruh terhadap pengungkapan manajemen risiko.

H5: Kepemilikan publik berpengaruh terhadap pengungkapan manajemen risiko.

\section{METODE PENELITIAN}

Penelitian ini merupakan penelitian kuantitatif. Dilihat dari sumber data penelitian ini merupakan data sekunder yaitu menggunakan laporan tahunan dari industri manufaktur yang terdaftar di Bursa Efek Indonesia pada tahun 2007-2011 yang telah dipublikasikan. Jika dilihat dari tujuan penelitian, penelitian ini termasuk penelitian kausal, yaitu penelitian yang bertujuan untuk melihat pengaruh antar variabel satu dengan variabel yang lain.

\section{Batasan Penelitian}

Penelitian ini dibatasi pada perusahaan sektor manufaktur yang terdaftar di Bursa Efek Indonesia (BEI) periode 2007-2011.

\section{Identifikasi Variabel}

Variabel dalam penelitian ini akan diidentifikasikan sebagai berikut : (1) Ukuran Prusahaan (2) Kepemilikan Manajemen (3) Kepemilikan Institusi Domestik (4) Kepemilikan Institusi Asing (5) Kepemilikan Publik (6) Pengungkapan Manajemen Risiko.

\section{Definisi Operasional dan Pengukuran Variabel}

\section{Ukuran Perusahaan}

Besar (ukuran) perusahan dapat dinyatakan dalam total aktiva, penjualan, dan kapitalisasi pasar (Sudarmadji dan Sularto, 2007). Pembagian ukuran besar atau kecilnya perusahaan berdasarkan atas ketentuan BAPEPAM No. 11/PM/1997 yang menyatakan bahwa perusahaan menengah atau kecil adalah perusahaan yang memiliki jumlah kekayaan (total asset) tidak lebih dari 100 milyar rupiah.

Ukuran Perusahaan $=$ total asset

\section{Kepemilikan Manajerial}

Kepemilikan manajemen adalah persentase kepemilikan pihak manajemen yang aktif dalam mengelola perusahaan atau dewan direksi atas saham perusahaan (Priyo Widodo, 2010). Kepemilikan manajemen dapat dinyatakan dengan rumus: 
$\mathrm{KM}=\underline{\Sigma}$ saham yang dimiliki dewan direksi

$\Sigma$ saham yang beredar

\section{Kepemilikan Institusi Domestik}

Kepemilikan saham perusahaan yang mayoritas dimiliki oleh institusi atau lembaga (perusahaan asuransi, bank, perusahaan investasi, asset management dan kepemilikan institusi lain) (Ririn, 2011). Kepemilikan instansi domestik dapat dinyatakan dalam rumus:

$\mathrm{KID}=\underline{\Sigma}$ saham dimiliki institusi domestik

$\Sigma$ saham yang beredar

\section{Kepemilikan Institusi Asing}

Kepemilikan asing adalah perseorangan warga negara asing, badan usaha asing, dan pemerintah asing yang melakukan penanaman modal di wilayah Republik Indonesia (Fathimiyah dkk, 2011). Dapat dinyatakan dengan rumus:

$\mathrm{KIA}=\underline{\Sigma}$ saham yang dimiliki institusi asing

$\Sigma$ saham yang beredar

\section{Kepemilikan Publik}

Kepemilikan saham publik adalah porsi saham beredar yang dimiliki masyarakat (Puspitasari,2009). Kepemilikan publik adalah kepemilikan masyarakat umum (bukan intitusi yang signifikan) terhadap saham perusahaan publik.dimana rumus atau formula adalah :

$\mathrm{KP}=\underline{\underline{\Sigma} \text { saham yang dimiliki publik }}$

$\underline{\Sigma}$ saham yang beredar

\section{Pengungkapan Manajemen Risiko}

Peraturan Bapepam Nomor : SE-02/PM/2002 tentaang Pedoman Penyajian dan Pengungkapan Laporan Keuangan Emiten atau Perusahaan Publik: Industri Manufaktur, menjelaskan terdapat sebelas risiko yang dihadapi industri manufaktur. Rumusan untuk menghitung pengungkapan Manajemen Risiko dinyatakan Fathimiya dkk (2011) sebagai berikut:

DSCORE BY $=\frac{1}{\text { AX BY i }=1} \stackrel{\sum \text { SCORE }}{\text { n }}$

\section{Populasi, Sampel dan Teknik Pengambilan Sampel}

Populasi yang digunakan dalam penelitian ini adalah Sektor Manufaktur yang tercatat di Bursa Efek Indonesia dari tahun 2007-2011. Pengambilan sampel dalam penelitian ini adalah bersifat purposive sampling, dengan kata lain, sampel diambil secara cermat sehingga relevan dengan tujuan penelitian dengan catatan sampel tersebut dapat mewakili populasi. 
Adapun kriteria yang digunakan dalam menentukan sampel yaitu: (1) Perusahaan manufaktur yang tetap listing di Bursa Efek Indonesia selama tahun 2007-2011. (2) Perusahaan manufaktur yang melaporkan laporan tahunannya serta melaporkan manajemen risiko sesuai dengan peraturan Bapepam Nomor : SE-02/PM/2002 selama periode pengamatan yaitu tahun 2007-2011. (3) Perusahaan manufaktur yang menerbitkan laporan keuangan yang dinyatakan dalam rupiah dan berakhir pada tanggal 31 Desember selama periode pengamatan tahun 2007-2011

\section{Data dan Metode Pengumpulan Data}

Data yang digunakan dalam penelitian ini adalah data sekunder, yaitu data primer yang telah diolah lebih lanjut dan disajikan baik oleh pihak pengumpul data pimer atau oleh pihak lain misalnya dalam bentuk tebel-tabel atau diagram (Puspitasari, 2009). Adapun data sekunder dalam penelitian ini adalah laporan tahunan perusahaan manufaktur yang telah dipublikasikan sejak tahun 2007 sampai 2011 yang diperoleh dari website Bursa Efek Indonesia.

\section{Teknik Analisis Data}

Untuk mengolah data dan menarik kesimpulan, maka peneliti menggunakan program SPSS version 16.00 for windows. Tahap-tahap yang dilakukan dalam melakukan teknik menganalisis data adalah sebagai beikut : (1) Mengumpulkan data-data laporan tahunan perusahaan publik untuk tahun 2007 sampai 2011, (2) Memilih data-data laporan tahunan perusahaan public yang akan diteliti sesuai dengan kriteria sampel yang telah ditentukan, (3) Menginput semua data yang menjadi variabel atas setiap perusahaan yang dijadikan sampel penelitian, dan (4) Menggunakan uji statistik data.

\section{Uji normalitas data}

Uji normalitas data (Kolmogorov-Smirnov Test) bertujuan untuk melihat apakah data model regresi telah terdistribusi dengan normal. Model regresi dapat dinyatakan telah terdistribusi normal jika nilai signifikannya $>0,05$. Maka diharapkan dalam penelitian akan didapat nilai signifikan $>0,05$.

\section{Analisis Regresi Linier Berganda}

\section{( Multiple Liner Regression )}

Untuk menguji hubungan antara variabel dependen dan variabel independen, maka peneliti menggunakan persamaan regresi berikut :

$Y=\alpha+\beta_{1} X_{1}+\beta_{2} X_{2}+\beta_{3} X_{3}+\beta_{4} X_{4}+\beta_{5} X_{5}+e$

Keterangan:

$\mathrm{Y}=$ Pengungkapan manajemen risiko

$\alpha=$ Konstanta

$\beta_{1}=$ Koefisien regresi ukuran perusahaan

$\beta_{2}=$ Koefisien regresi kepemilikan manajemen

$\beta_{3}=$ Koefisien regresi kepemilikan instansi domestik

$\beta_{4}=$ Koefisien regresi kepemilikan instansi asing 
$\beta_{5}=$ Koefisien regresi kepemilikan publik

$\mathrm{X}_{1}=$ Ukuran perusahaan

$\mathrm{X}_{2}=$ Kepemilikan manajemen

$\mathrm{X}_{3}=$ Kepemilikan instansi domestik

$\mathrm{X}_{4}=$ Kepemilikan instansi asing

$\mathrm{X}_{5}=$ Kepemilikan publik

$\mathrm{e} \quad=$ Standard error

\section{Koefisien Determinasi}

Koefisien determinasi (R2) bertujuan untuk menentukan kemampuan variabel independen dalam menjelaskan variasi variabel dependen. Nilai koefisien determinasi adalah antara 0 (nol) dan 1 (satu).

\section{Uji F}

Digunakan untuk menguji apakah model regresi yang digunakan sudah tepat ataukah belum. Model regresi dikatakan fit jika nilai $\mathrm{F}$ hitung $<0,05$. Diharapkan probabilitas dari $\mathrm{F}$ hitung $<0,05$ yang memiliki arti bahwa model regresi dapat digunakan untuk memprediksi pengungkapan manajemen risiko.

\section{Uji t}

Uji statistika t pada dasarnya menunjukkan seberapa jauh pengaruh satu variabel independen terhadap variabel dependen (Imam, 2006). Ketentuan yang digunakan dalam uji t adalah sebagai berikut: (1) Jika signifikan < 0,05, maka variabel independen berpengaruh terhadap variabel dependen (2) Jika nilai signifikan > 0,05, maka variabel independen tidak berpengaruh terhadap variabel dependen.

\section{ANALISIS DATA DAN PEMBAHASAN}

\section{Uji Normalitas}

Tabel 1

Uji Normalitas Awal

\begin{tabular}{|c|c|}
\hline & $\begin{array}{c}\text { Unstandar } \\
\text { dized } \\
\text { Residual }\end{array}$ \\
\hline Jumlah Sampel & $\mathbf{1 8 9}$ \\
\hline Kolmogorov-Smirnov Z & $\mathbf{1 , 8 4 2}$ \\
\hline Asymp.Sig. (2-tailed) & $\mathbf{0 , 0 0 2}$ \\
\hline
\end{tabular}

Berdasarkan pada tabel 1 diatas, nilai Kolmogorov - smirnov Z sebesar 1,842 dengan Asymp. Sig (2-tailed) yaitu sebesar 0,002, nilai ini lebih kecil dari nilai signifikansi yaitu $0,000<0,05$ yang berarti data tidak terdistribusi normal. Sehingga untuk menormalkan data, dilakukan dengan cara mengkonversi nilai data ke dalam skor standardized atau yang biasa disebut Z-score. Setelah membuang data outlier peneliti melakukan pengujian kembali atas data dengan menggunakan uji Kolmogorov - smirnov. 
Tabel 2

Uji Normalitas Akhir

\begin{tabular}{|c|c|}
\hline & $\begin{array}{c}\text { Unstandar } \\
\text { dized } \\
\text { Residual }\end{array}$ \\
\hline Jumlah Sampel & $\mathbf{1 4 1}$ \\
\hline Kolmogorov-Smirnov Z & $\mathbf{1 , 3 1 2}$ \\
\hline Asymp.Sig. (2-tailed) & $\mathbf{0 , 0 6 4}$ \\
\hline
\end{tabular}

Berdasarkan tabel diatas, setelah dilakukan uji kembali dengan sebelumnya mentransfom data, didapatkan nilai Kolmogorov - smirnov Z sebesar 1,312 dengan Asymp. Sig (2-tailed) sebesar 0,064. Dengan kata lain, model regresi tersebut telah terdistribusi secara normal karena nilai signifikansi $>0,05$.

\section{Analisis Regresi Linear Berganda}

Tabel 3

HASIL UJI REGRESI

Coeffisients $^{\mathrm{a}}$

\begin{tabular}{|l|r|r|}
\hline \multirow{2}{*}{ Model } & \multicolumn{2}{|c|}{ Unstandardized Coefficients } \\
\cline { 2 - 3 } & \multicolumn{1}{|c|}{ B } & \multicolumn{2}{|c|}{ Std. Error } \\
\hline Constant) & 5,273 & 1,027 \\
\hline TA & 0,115 & 0,119 \\
\hline KM & 31,290 & 39,466 \\
\hline KID & $-2,171$ & 0,881 \\
\hline KIA & $-2,573$ & 0,885 \\
\hline KP & $-2,641$ & 1,001 \\
\hline
\end{tabular}

Berdasarkan tabel 3, maka model persamaan regresi linear berganda diperoleh sebagai berikut :

$$
\mathrm{Y}=5,273-2,171 \mathrm{KID}-2,573 \mathrm{KIA}-2,641 \mathrm{KP}
$$

Interpretasi dari model regresi di atas adalah : 
1. Konstanta $(\alpha)$ sebesar $+5,273$ menyatakan bahwa jika variabel independen dianggap konstan, maka pengungkapan manajemen risiko akan naik sebesar 5,273 persen.

2. Koefisien regresi $\left(\beta_{1}\right)$ untuk TA sebesar $+0,115$ menyatakan bahwa setiap perubahan satu satuan pada total asset dengan asumsi variabel lainnya tetap, maka pengugngkapan manajemen risiko akan mengalami penurunan sebesar 2,641 persen.

3. Koefisien regresi $\left(\beta_{2}\right)$ untuk KM sebesar $+31,290$ menyatakan bahwa setiap perubahan satu satuan pada kepemilikan saham manajemen dengan asumsi variabel lainnya tetap, maka pengungkapan manajemen risiko akan mengalami kenaikan sebesar 31,290 persen.

4. Koefisien regresi $\left(\beta_{3}\right)$ untuk KID sebesar - 2,171 menyatakan bahwa setiap perubahan satu satuan pada kepemilikan saham institusi domestik dengan asumsi variabel lainnya tetap, maka pengungkapan manajemen risiko akan mengalami penurunan sebesar 2,171 persen.

5. Koefisien regresi $\left(\beta_{4}\right)$ untuk KIA sebesar - 2,573 menyatakan bahwa setiap penambahan satu satuan kepemilikan institusi asing akan menurunkan pengungkapan manajemen risiko sebesar 2,573 persen.

6. Koefisien regresi $\left(\beta_{5}\right)$ untuk KP sebesar - 2,641 menyatakan bahwa setiap perubahan satu satuan pada kepemilikan publik dengan asumsi variabel lainnya tetap, maka pengungkapan manajemen risiko akan mengalami penurunan sebesar 2,641 persen.

7. Error

\section{Koefisien Determinasi}

Tabel 4

KOEFISIEN DETERMINASI

Model Summary ${ }^{b}$

\begin{tabular}{|l|r|}
\hline Model & Adjusted R Square \\
\hline 1 & 0,045 \\
\hline
\end{tabular}

Berdasarkan dalam tabel 4, nilai adjusted $\mathrm{R}^{2}$ adalah 0,045 hal ini berarti hanya 4,5 persen variabel dependen pengungkapan manajemen risiko dapat dijelaskan oleh keempat variabel independen yakni TA, KM, KID, KIA, dan KP. Sedangkan sisanya 95,5 persen dijelaskan oleh variabel - variabel lain di luar model. 


\section{Uji F}

Tabel 5

HASIL UJI F

ANOVA ${ }^{b}$

\begin{tabular}{|c|c|c|c|}
\hline Model & & $\mathrm{F}$ & Sig. \\
\hline 1 & $\begin{array}{l}\text { Regression } \\
\text { Residual } \\
\text { Total }\end{array}$ & 2,312 & $0,047^{\mathrm{a}}$ \\
\hline
\end{tabular}

Berdasarkan hasil output SPSS pada tabel 5 diatas, diketahui $\mathrm{F}$ hitung sebesar 2,312 dengan tingkat signifikan $0,047<0,05$. Hal ini berarti model regresi dapat dipakai untuk memprediksi nilai perusahaan atau model regresi fit dengan data.

\section{Uji Parsial (t test)}

Tabel 6

HASIL UJI REGRESI

Coeffisients $^{\text {a }}$

\begin{tabular}{|l|c|c|}
\hline Model & \multicolumn{1}{|c|}{$\mathrm{t}$} & Sig. \\
\hline (Constant) & 5,135 & 0,000 \\
\hline TA & 0,968 & 0,335 \\
\hline KM & 0,793 & 0,429 \\
\hline KID & $-2,465$ & 0,015 \\
\hline KIA & $-2,906$ & 0,004 \\
\hline KP & $-2,639$ & 0,009 \\
\hline
\end{tabular}

Berdasarkan hasil analisis data dengan menggunakan regresi dapat dilihat pada tabel 6 diketahui hasil pengujian signifikansi variabel independen secara parsial sebagai berikut : Pertama, tidak terdapat pengaruh antara ukuran perusahaan terhadap pengungkapan manajemen risiko. Pengujian hipotesis ini ditunjukkan dengan nilai t hitung dari hasil output SPSS sebesar 0,968, dengan nilai signifikansi sebesar 0,335>0,05. Hal ini berarti H0 diterima yang artinya bahwa ukuran perusahaan tidak berpengaruh terhadap nilai perusahaan. 
Dengan demikian hipotesis yang menyebutkan terdapat pengaruh antara ukuran perusahaan terhadap pengungkapan manajemen risiko tidak dapat diterima.

Kedua, tidak terdapat pengaruh antara kepemilikan manajemen terhadap pengungkapan manajemen risiko. Pengujian hipotesis ini ditunjukkan dengan nilai t hitung dari hasil output SPSS sebesar 0,793, dengan nilai signifikansi sebesar 0,429>0,05. Hal ini berarti $\mathrm{H} 0$ diterima yang artinya bahwa kepemilikan manajemen tidak berpengaruh terhadap nilai perusahaan. Dengan demikian hipotesis yang menyebutkan terdapat pengaruh antara kepemilikan manajemen terhadap pengungkapan manajemen risiko tidak dapat diterima

Ketiga, terdapat pengaruh antara kepemilikan institusi domestik terhadap pengungkapan manajemen risiko. Pengujian hipotesis ini ditunjukkan dengan nilai t hitung dari hasil output SPSS sebesar -2,465, dengan nilai signifikansi sebesar 0,015 < 0,05. Hal ini berarti $\mathrm{H} 0$ ditolak yang artinya bahwa kepemilikan institusi domestik berpengaruh terhadap pengungkapan manajemen risiko. Dengan demikian hipotesis yang menyebutkan terdapat pengaruh antara kepemilikan institusi domestik terhadap pengungkapan manajemen risiko dapat diterima.

Keempat, terdapat pengaruh antara kepemilikan institusi asing terhadap pengungkapan manajemen risiko. Pengujian hipotesis ini ditunjukkan dengan nilai t hitung dari hasil output SPSS sebesar -2.906, dengan nilai signifikansi sebesar 0,004 < 0,05. Hal ini berarti H0 ditolak yang artinya bahwa kepemilikan institusi asing berpengaruh terhadap pengungkapan manajemen risiko. Dengan demikian hipotesis yang menyebutkan terdapat pengaruh antara kepemilikan institusi asing terhadap pengungkapan manajemen risiko dapat diterima.

Kelima, terdapat pengaruh antara kepemilikan publik terhadap pengungkapan manajemen risiko. Pengujian hipotesis ini ditunjukkan dengan nilai t hitung dari hasil output SPSS sebesar -2,639, dengan nilai signifikansi sebesar 0,009 $<0,05$. Hal ini berarti H0 ditolak yang artinya bahwa kepemilikan publik berpengaruh terhadap pengungkapan manajemen risiko. Dengan demikian hipotesis yang menyebutkan terdapat pengaruh antara kepemilikan publik terhadap pengungkapan manajemen risiko dapat diterima.

\section{PEMBAHASAN}

\section{Pengaruh ukuran perusahaan terhadap pengungkapan manajemen risiko}

Semakin besar perusahaan, maka semakin banyak pula detail-detail informasi yang akan disajikan. Perusahaan besar dituntut untuk melakukan hal tersebut karena mereka dianggap mampu untuk menunjukkan informasi yang lebih detail.

Hipotesis pertama menyatakan bahwa ukuran perusahaan tidak berpengaruh terhadap pengungkapan manajemen risiko. Dalam memberikan informasi perusahaan terhadap pihak luar, manajemen akan memperhitungkan seberapa biaya yang akan dibutuhkan dan seberapa besar pula manfaat yang akan mereka dapatkan dari biaya yang telah mereka keluarkan.

Hasil ini bertolak belakang dengan penelitian yang dilakukan oleh Puspitasari (2009) yang menyatakan bahwa ukuran perusahaan memiliki hubungan dengan tingkat pengungkapan laporan tahunan. Perbedaan hasil ini dapat terjadi dikarenakan belum banyak perusahaan yang mematuhi peraturan Bapepam Nomor : SE-02/PM/2002. Sedikit sekali perusahaan yang menganggap pengungkapan manajemen risiko itu penting, hal ini terlihat 
dari jumlah perusahaan yang melaporkan laporan tahunannya dengan menyertakan informasi tentang manajemen risiko yang hanya terdiri dari 189 perusahaan.

\section{Pengaruh kepemilikan manajemen terhadap pengungkapan manajemen risiko}

Manajemen bertanggung jawab atas semua kegiatan usaha yang telah dilakukan dengan melakukan pengungkapan laporan tahunan. Semakin besar proporsi kepemilikan manajerial pada perusahaan, maka manajemen cenderung lebih giat untuk kepentingan pemegang saham dimana pemegang saham adalah dirinya sendiri yaitu dengan lebih detail dalam pengungkapan manajemen risiko.

Hipotesis kedua menyatakan bahwa kepemilikan manajemen tidak berpengaruh terhadap nilai perusahaan. Semakin tinggi kepemilikan manajemen suatu perusahaan menyebabkan semakin besar pula tanggung jawab manajemen dalam mengambil keputusan dan resiko pun menjadi semakin tinggi (Fathimiyah dkk, 2011). Manajemen yang memiliki peran ganda, yaitu sebagai pelaksana perusahaan serta pemegang saham tidak memberikan dampak terhadap pengungkapan manajemen risiko. Manajemen bertindak sebagai pelaksana perusahaan telah mengetahui risiko-risiko yang dihadapi perusahaan walaupun tidak diungkapkan dalam laporan tahunannya. Manajemen juga akan memperhitungkan biaya yang akan dikeluarkan dari pengungkapan tersebut, kerena mereka telah mengetahui informasi tersebut maka dirasa tidah perlu untuk diungkapkan kembali dalam laporan tahunan.

Hasil ini mendukung penelitian sebelumnya yang dilakukan Fathimiyah dkk (2011), menyatakan bahwa kepemilikan manajemen tidak berpengaruh terhadap pengungkapan risk management.

\section{Pengaruh kepemilikan institusi domestik terhadap pengungkapan manajemen risiko}

Kepemilikan institusi domestik merupakan kepemilikan saham perusahaan yang mayoritas dimiliki oleh institusi atau lembaga (perusahaan asuransi, bank, perusahaan investasi, asset management dan kepemilikan institusi lain). Kepemilikan institusional merupakan pemegang saham terbesar sehingga merupakan sarana untuk memonitor manajemen.

Hipotesis ketiga menyatakan bahwa kepemilikan institusi domestik berpengaruh terhadap pengungkapan manajemen risiko. Semakin besar kepemilikan institusi domestik, maka pengawasan yang diterima perusahaan semakin besar pula. Hal tersebut membuat perusahaan akan semakin tidak dapat berbuat seenaknya atau melakukan penyelewenganpenyelewengan.

Peningkatan kepemilikan institusi domestik menyebabkan pengawasan terhadap kinerja manajemen semakin optimal karena dapat mengendalikan perilaku manajemen. Dengan begitu perusahaan juga dapat dijalankan lebih efisien dan efektif. Hal tersbut dapat mengurangi risiko yang dihadapi perusahaan. Semakin sedikit risiko yang dihadapi perusahaan maka semakin sedikit pula pengungkapan manajemen risiko yang diperlukan.

Hasil penelitian ini berbeda dengan penelitian yang telah dilakukan oleh Hapsoro (2007), yang menyatakan bahwa kepemilikan institusi domestik tidak berpengaruh terhadap tingkat transparansi. Hasil ini juga berbeda dengan hasil penelitian Fathimiyah dkk (2011) yang menyatakan bahwa kepemilikan institusi domestik tidak berpengaruh terhadap risk management disclosure. Perbedaan sektor industri yang menjadi pilihan penelitian sekarang dan yang terdahulu mungkin menyebabkan terjadinya perbedaan tersebut. Kontrol yang semakin ketat dari intitusi domestik dapat pula menyebabkan pihak manjemen untuk melaporkan manajemen risiko sesuai dengan peraturan yang berlaku karena hal tersebut 
merupakan salah satu informasi yang dibutuhkan oleh pemegang saham, tidak terkecuali oleh institusi domestik.

\section{Pengaruh Kepemilikan Institusi Asing terhadap pengungkapan manajemen risiko}

Menurut Undang-undang No. 25 Tahun 2007 pada pasal 1 angka 6 kepemilikan asing adalah perseorangan warga negara asing, badan usaha asing, dan pemerintah asing yang melakukan penanaman modal di wilayah Republik Indonesia.

Hipotesis keempat menyatakan bahwa kepemilikan institusi asing berpengaruh terhadap pengungkapan manajemen risiko. Kepemilikan institusi asing menjadikan pihak manajemen lebih meningkatkan mutu kinerjanya karena pihak asing mempunyai standar yang tinggi sehingga semakin tinggi kepemilikan asing yang dimiliki perusahaan, mereka akan menunjukan bagamana cara-cara yang telah ditempuh untuk menanggulani risiko-risiko yang dihadapi perusahaan. Selain itu adanya standar tinggi yang diharapkan dari pihak asing tersebut membuta perusahaan dikelola lebih baik untuk mengurangi kemungkinan risiko yang akan dihadapi perusahaan, sehingganantinya manajemen risiko yang perlu diungkapkan akan semakin sedikit pula.

Semakin tingginya kepemilikan institusi asing dapat dikatakan juga meningkatnya utang asing akibat dari aliran modal asing yang masuk keperusahaann, hal ini meningkatkan pengungkapan manajemen risiko yang dibutuhkan oleh para pemegang saham asing tersebut.

Hasil ini tidak sama dengan hasil penelitian Hapsoro (2007) yang menyatakan kepemilikan institusi asing tidak berpengaruh terhadap tingkat transaparansi. Hasil ini juga bertolak belakang dengan yang dilakukan Fathimiyah dkk (2011) yang menyatakan bahwa kepemilikan institusi asing tidak berpengaruh terhadap risk management disclosure.

\section{Pengaruh kepemilikan publik terhadap pengungkapan manajemen risiko}

Kepemilikan perusahaan oleh pihak luar memiliki kekuatan yang besar dalam memengaruhi perusahaan melealui media massa berupa kritikan atau komentar yang semuanya dianggap sebagai suara masyarakat.

Hipotesis kelima menyatakan bahwa kepemilikan publik berpengaruh terhadap pengungkapan manajemen risiko. Kepemilikan publik mempunyai arti yang sangat penting untuk perusahaan. Semakin banyak pihak yang membutuhkan informasi tentang perusahaan, Di lain pihak, manajemen harus selektif dalam melakukan pengungkapan informasi karena pengungkapan informasi mengandung biaya. Manajemen hanya akan mengungkapakan informasi jika informasi tersebut memberikan manfaat yang lebih besar dari pada biaya yang dikeluarkan. Untuk tetap memberikan informasi yang dibutuhkan para pemegang saham dan juga meminimalkan biaya yang dikeluarkan untuk mengungkapkan informasi, perusahaan dapat menempuh jalan dengan lebih efisien dsan efektif dalam menjalankan perusahaannya. Dengan demikian risiko yang dihadapi perusahaan berkurang, secara otomatis akan mengurangi pula manajemen risiko yang perlu diungkapkan.

Hasil ini sama dengan penelitian yang dilakukan Hapsoro (2007) yang menyatakan kepemilikan publik berpengaruh terhadap transparansi. Demikian pula dengan penelitian yang dilakukan Kartika (2009) yang menyatakan kepemilikan saham publik berpengaruh terhadap indeks pengungkapan. Tetapi hasil ini bertolak belakang dengan yang dilakukan oleh Fathimiyah dkk (2011) yang menyatakan bahwa kepemilikan publik tidak berpengaruh terhadap risk management disclosure. Hasil ini juga berbeda dengan hasil penelitian dari pusitasari (2009) yang menyatakan kepemilikan publik tidak berpengaruh terhadap tingkat pengungkapan laporan tahunan. Tetapi Puspitasari (2009) menyatakan kepemilikan publik 
berpengaruh positif secara simultan berpengaruh positif terhadap tingkat pengungkapan laporan tahunan.

\section{KESIMPULAN, KETERBATASAN DAN SARAN}

Penelitian ini memiliki tujuan untuk meneliti pengaruh struktur kepemilikan dan ukuran perusahaan terhadap pengungkapan manajemen risiko pada perusahaan sektor manufaktur tahun 2007 hingga tahun 2011 yang terdaftar di Bursa Efek Indonesia (BEI). Data yang digunakan dalam penelitian ini adalah data sekunder yang didapat dari yang bersumber dari Indonesia Exchange (IDX). Total perusahaan yang terdaftar selama periode penelitian yakni 147 perusahaan dikalikan dengan 5 tahun pengamatan menjadi 735 perusahaan, namun setelah melakukan purposive sampling data untuk mendapatkan sampel yang dibutuhkan untuk pengujian, didapat sebanyak 189 perusahaan. Data sampel perusahaan sebanyak 189 pengamatan sebelum data di outlier. Namun setelah dilakukan outlier data maka jumlah sampel pengamatan berkurang menjadi sebanyak 141 perusahaan selama tahun $2007-2011$.

Penelitian ini menggunakan uji analisis regresi berganda untuk membuktikan hipotesisnya. Berdasarkan hasil pengujian, kesimpulan yang dapat diperoleh adalah sebagai berikut: Hasil penelitian menunjukan variabel kepemiliklan institusi domestik, kepemilikan institusi asing dan kepemilikan publik berpengareuh terhadap pengungkapan manajemen risiko. Hal ini dapat disebabkan karena semakin besar kontrol yang diberikaan oleh pihak eksternal menyebabkan pihak manajemen lebih efisien dan efektif dalam menjalankan perusahaan sehingga meminimalisasi risiko yang dihadapi sehingga hanya sedikit manajemen risiko yang diungkapkan. Sedangkan ukuran perusahaan dan kepemilikan manajemen tidak berpengaruh, karena pihak manajemen yang memiliki peran ganda sebagai pengelola perusahaan dan pemegang saham, mengetahui risiko apa saja yang dihadapi perusahaan walaupun tanpa diungkapkan dalam laporan tahunan.

Tingkat kepatuhan perusahaan manufaktur dalam mengungkapkan manajemen risiko mencapai 51,46\%. Walaupun pengungkapan butir-butirnya masih sedikit, hal ini terlihat dari jumlah pengungkapan manajemen risiko terbanyak hanya mencapai enam butir dari sebelas butir yang telah diatur dalam Peraturan Bapepam Nomor : SE-02/PM/2002 tentaang pedoman penyajian dan pengungkapan laporan keuangan emiten atau perusahaan publik: industri manufaktur.

Keterbatasan penelitian yang diperoleh selama penelitian berlangsung adalah sebagai berikut: (1) Data yang telah di tabulasi oleh peneliti terdapat nilai ekstrim sehingga diharuskan membuang data yang ourlier untuk mendapatkan data yang terdistribusi normal. (2) Perusahaan yang melaporkan laporan tahunananya secara berturut-turut dari 2007-2011 sangat sedikit sehingga sampel diganti dengan perusahaan yang melaporkan laporan tahunannya pada tahun2007-2011.

Saran yang diberikan dalam penelitian ini adalah sebagai berikut: (1) Penelitian selanjutnya mungkin bisa menggunakan seluruh perusahaan yang terdaftar di BEI sebagai sampel penelitian ,atau dengan membandingkan tingkat kepatuhan setiap sektor industri dalam pelaporan menejemen risiko. (2) Penelitian selanjutnya hendaknya mempertimbangkan penggunaan variabel lain yang mungkin mempengaruhi pengungkapan manajemen risiko seperti umur perusahaan. 
DAFTAR RUJUKAN

Amran, A., Abdul Manaf Rosli Bin and Bin Che Haat Mohd Hassan. 2009. Risk reporting An exploratory study on risk managementdisclosure in Malaysian annual reports. Vol. 24 No. 1, pp 39-57.

Bank Indonesia. 2003. "Penerapan Manajemen Risiko Bagi Bank Umum". NOMOR: 5/8/PBI/2003.

BAPEPAM. 2002. Surat Edaran Ketua Badan Pengawas Pasar Modal Nomor : SE - 02/PM / 2002 Tanggal : 27 Desember 2002 tentang Pedoman Penyajian dan Pengungkapan Laporan Keuangan Emiten atau Perusahaan Publik Industri Manufaktur. Jakarta. Badan Pengawas Pasar Modal.

Darwis, Herman. 2009. “Corporate Governance Terhadap Kinerja Perusahaan”. Jurnal Keuangan dan Perbankan. Vol. 13, No. 3. Hal. 418-430

Dewi, Kumala. 2009. "Pengaruh Luas Pengungkapan Laporan Keuangan Tahunan Pada Perusahaan Manufaktur Di Bursa Efek Indonesia Terhadap Pengambilan Keputusan Oleh Investor".Skripsi. Universitas Gunadarma.

Diyah, Pujiati dan Widanar, Erman. 2009. "Pengaruh Struktur Kepemilikan Terhadap Nilai Perusahaan: Keputusan Keuangan sebagai Variabel Intervening." Jurnal Ekonomi Bisnis dan Akuntansi Ventura, Vol. 12. No.1, h. 71-86

Dwi, Theresia H. 2005. "hubungan antara good corporate governance dan struktur kepemilikan dengan kinerja keuangan”. SNA VIII Solo, 15 - 16 September 2005.

Djakman Chaerul D., Machmud, Novita. 2008. "Pengaruh Struktur Tahunan Perusahaan". Simposium Nasional Akuntansi XI, Pontianak.

Fathimiyah, Venny. Rudi Zulfikar dan Fara Fitriani. 2011. "Pengaruh Struktur Kepemilikan Terhadap Risk Management Disclosure (Studi Survei Industri Perbankan Yang Listing Di Bursa Efek Indonesia Tahun 2008-2010)". Skripsi. Universitas Sultan Ageng Tirtayasa.

Fuad, Muhamad. 2006. "Uji Empiris Faktor-Faktor Yang Mempengaruhi Disclosure Perusahaan Manufaktur di BEJ".Akuntabilitas, ISSN 1412-0240 Vol.6, no. 1, Hal. 80-87.

Gozali, Imam. 2006. "Aplikasi Analisis Multivariate dengan Program SPSS”. Badan Penerbitan Universitas Diponogoro.

Hapsoro, Dody. 2007. "Pengaruh Struktur Kepemilikan Terhadap Transparansi: Studi Empiris Di Pasar Modal Indonesia”. Jurnal Akuntansi dan Manajemen. VOL. 18, NO. 2, Hal. 65-85.

Hidayah, Erna. 2008. "Pengaruh Kualitas Pengungkapan Informasi Terhadap Hubungan Antara Penerapan Corporate Governance Dengan Kinerjaa Perusahaan Di Bursa Efek Jakarta”. Skripsi. Universitas Islam Indonesia. 
Kartika, Andi. 2009. "Faktor-Faktor Yang Mempengaruhi Kelengkapan Pengungkapan Laporan Keuangan Pada Perusahaan Manufaktur Yang Terdaftar Di Bursa Efek Indonesia. Kajian Akuntansi., Vol. 1, No. 1, Hal: 29-47.

Nuswandari, Cahyani. 2009."Pengungkapan Pelaporan Keuangan Dalam Perspektif Signalling Theory.”. Kajian Akuntansi., Vol. 1, No. 1, Hal: 48-57.

Puspitasari. 2009."Hubungan Ukuran Perusahaan Dan Porsi Kepemilikan Saham Publik Dengan Tingkat Pengungkapan Laporan Tahunan Perusahaan”. Skripsi. Universitas Pendidikan Indonesia.

Prayogi. 2003. "Pengaruh Karakteristik Perusahaan Terhadap Luas Pengungkapan Laporan Keuangan Perusahaan Yang Terdaftar Dalam Bursa Efek Jakarta”. Skripsi. UNDIP. Semarang.

Setiawan, maman., et al. 2006. "Pengaruh Struktur Kepemilikan, Karakteristik Perusahaan, Dan Karakteristik Tata Kelola Korporasi Terhadap Kinerja Perusahaan”. (Online), (http://pustaka.unpad.ac.id, diakses 29 September 2012)

Spica, Lusiana A., dan I. Retrinasari. 2007. "Analisis Pengaruh Karakteristik Perusahaan Terhadap Kelengkapan Pengungkapan Dalam Laporan Tahunan Perusahaan Manufaktur Yang Terdaftar Di Bej”. Proceeding Seminar Nasional Inovasi dalam Menghadapi Perubahan Lingkungan Bisnis. FE Universitas Trisakti Jakarta

Sudarmadji, Ardi Murdoko. 2007. Pengaruh Ukuran Perusahaan, Profitabilitas, Leverage, dan Tipe Kepemilikan Perusahaan Terhadap Luas Voluntary Disclosure Laporan Keuangan Tahunan. Vol 2, ISSN : 1858-2559.

Suhardjanto, Djoko. 2010. "Pengungkapan Risiko Finansial dan Tata Kelola Perusahaan: Studi Empiris Perbankan Indonesia”. Jurnal Keuangan dan Perbankan. Vol. 15, No. 1, Hal. 105-118.

Suranta, Edi dan Puspita, Pratama Merdistuti. 2003 “Analisis Hubungan Struktur Kepemilikan Manajerial, Nilai Perusahaan dan Investasi dengan Model Persamaan Linear Simultan”. Jurnal Riset Akuntansi Indonesia, Vol. 6, No. 1, h. 54-68

Ujiyantho, Arif Muh. dan B.A. Pramuka. 2007. "Mekanisme Corporate Governance, Manajemen Laba dan Kinerja Keuangan." Simposium Nasional Akuntansi X, Makasar, 26-28 Juli 